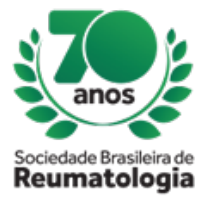

\title{
A NEW PEDIATRIC RHEUMATOLOGY UNIT IN NORTHEAST OF BRAZIL
}

CARLOS NOBRE RABELO-JÚNIOR (HOSPITAL GERAL DE FORTALEZA, FORTALEZA, CE, Brasil), MARCO FELIPE CASTRO DA SILVA (HOSPITAL GERAL DE FORTALEZA, FORTALEZA, CE, Brasil), ANA RAQUEL XAVIER FEITOSA (HOSPITAL GERAL DE FORTALEZA, FORTALEZA, CE, Brasil), MÍRIA PAULA VIEIRA CAVALCANTE (HOSPITAL GERAL DE FORTALEZA, FORTALEZA, CE, Brasil), NATALIA GOMES IANNINI (HOSPITAL GERAL DE FORTALEZA, FORTALEZA, CE, Brasil), LARISSA ELIAS PINHO (HOSPITAL GERAL DE FORTALEZA, FORTALEZA, CE, Brasil)

\section{BACKGROUND}

Pediatric rheumatology (PR) has been formally recognized for a few decades in Brazil, with medical training centers concentrated in southeast of country. The need to expand specialists number in area, as well as to improve health care of pediatric patients with rheumatic diseases in region, was the reason for creation of a new unit in Ceará.

\section{MATERIALS AND METHODS}

Descriptive and observational study about implementation of a PR unit in a tertiary public hospital in Ceará. Data were collected based on internal reports and electronic spreadsheets filled monthly since May 2010 and analyzed in May 2019.

\section{RESULTS}

This hospital has reference services in rheumatology and pediatrics, as well as medical residences in both areas, solid bases for creation of a well-structured PR unit. Outpatient care started in May 2010 and in March 2013 the PR medical residency was founded, being only one in North and Northeast of Brazil. This made it possible to increase specialists number from two in 2013 to six in 2019, performing in main public and private hospitals. The unit receives medical graduation students and medical residents of pediatrics and rheumatology, being currently a required practice scenario. The resident physician training is based on patients follow-up in inpatient and outpatient clinic of PR, but also has other action fields, such as infusion center of immunobiologics, infiltration outpatient clinic, outpatient clinics of orthopedic, immunology and dermatology, autoimmunity laboratory, among others. Regarding clinical research, the unit is included in multicentric Brazilian studies and counts on own scientific productions. It actively participates in local, national and international events, having already promoted two regional scientific ones (2017 and 2019) aimed at general rheumatologists and pediatric rheumatologists from the north and northeast, establishing as one of centers responsible for continuing education. With regard to health care, from May 2010 to May 2019, 2,168 patients were evaluated in 12,156 visits (1,350 visits / year), and currently 978 patients are in regular follow-up. Since 2013 to the present time, 928 hospital admissions were performed on the inpatient unit (154 / year).

\section{CONCLUSION}

Foundation of a specialized PR unit in Ceará, with increasing expansion and visibility in region, enables better health care for pediatric patients with rheumatic diseases. Although it is still a pediatric area with few professionals and practical fields still under construction, PR has been consolidating itself in academic medical education, mainly in conjunction with pediatrics and rheumatology. 